Article

\title{
Applying Responsible Ownership to Advance SDGs and the ESG Framework, Resulting in the Issuance of Green Bonds
}

\author{
Gudrun Erla Jonsdottir ${ }^{1, *(\mathbb{D}}$, Throstur Olaf Sigurjonsson ${ }^{2,3}$, Ahmad Rahnema Alavi ${ }^{4} \mathbb{D}_{\text {and Jordan Mitchell }}{ }^{5}$ \\ 1 School of Business, University of Iceland, 102 Reykjavík, Iceland \\ 2 Faculty of Business Administration, University of Iceland, 102 Reykjavik, Iceland; olaf@hi.is \\ Department of Accounting, Copenhagen Business School, 2000 Frederiksberg, Denmark \\ IESE Business School, Avenida Pearson, 21, 08034 Barcelona, Spain; ARahnema@iese.edu \\ 5 Independent Researcher, Toronto, ON M4T 1Z2, Canada; jordanmitchellnet@gmail.com \\ * Correspondence: gudrunerla@or.is; Tel.: +354-617-6335
}

Citation: Jonsdottir, G.E.;

Sigurjonsson, T.O.; Alavi, A.R.;

Mitchell, J. Applying Responsible

Ownership to Advance SDGs and the ESG Framework, Resulting in the Issuance of Green Bonds.

Sustainability 2021, 13, 7331. https:// doi.org/10.3390/su13137331

Academic Editor: Antonino Galati

Received: 29 May 2021

Accepted: 25 June 2021

Published: 30 June 2021

Publisher's Note: MDPI stays neutral with regard to jurisdictional claims in published maps and institutional affiliations.

Copyright: (c) 2021 by the authors. Licensee MDPI, Basel, Switzerland. This article is an open access article distributed under the terms and conditions of the Creative Commons Attribution (CC BY) license (https:// creativecommons.org/licenses/by/ $4.0 /)$.

\begin{abstract}
This study aimed to contribute to the strand of literature encompassing governance, sustainability, and stakeholder theory by addressing an inchoate element of responsible ownership: collective action by different stakeholders. Our study's originality rests on the introduction of an ownership strategy as a governance mechanism for collective action and responsible ownership in order to implement the United Nations Sustainable Development Goals (SDGs) and an environmental, social, and governance (ESG) framework. Using a twofold empirical methodology—studying of archival data and qualitative case work-we provide empirical evidence from a case study of a Nordic energy company showing that applying an ownership strategy helped to strengthen the approach to SDGs and ESG while leading to positive benefits: in this case, the issuance of green bonds. Our theoretical contribution is the addressing of a gap in the literature exploring how an ownership strategy can be a uniting point for collective action, based on the hypothesis that an ownership strategy provides an important reinforcement of a "virtuous cycle". Policymakers who are interested in promoting long-term commitment of different stakeholders with a focus on sustainability and improved agency should encourage the formulation of an ownership strategy that explains the owners' commitment to the environment, social causes, and/or governance guidelines. Therein lies the practical contribution of this work. In this study, we found that an ownership strategy with these elements helped to strengthen the firm's commitment to SDGs and ESG.
\end{abstract}

Keywords: governance; sustainability; responsible ownership; collective action; green bonds; SDGs; ESG framework

\section{Introduction}

The 17 Sustainable Developmental Goals (SDGs) were presented in the United Nations 2030 Agenda for Sustainable Development [1]. There is growing environmental awareness throughout the world; some organizations are adopting elements of the SDGs and including elements of corporate social responsibility (CSR) as part of their business goals. To date, research has focused on how stakeholders can set goals to align to the SDGs [2] and to address the challenges of implementing SDGs [3]. A growing body of research examines how firms can embed SDGs within their corporate strategy [4].

Recent theoretical and empirical studies seem to confirm the idea that ownership structure is important for building sustainable and responsible businesses. Different owners of a company typically have different goals and objectives for the company, which depend mainly on the time horizons of their investments. Institutional investors, such as mutual funds, usually have a shorter investment horizon than private equity funds, hedge funds, or family offices [5-7]. Similarly, while institutional investors typically seek to maximize the financial profitability of the firm (and hence the value of their investment), 
family offices often seek to maximize their socio-emotional wealth; in contrast, governments aim to improve the social welfare of all citizens $[8,9]$.

Today, the reality is that institutional investors (investing on behalf of others) actively control and significantly influence the management of companies around the world [10]. Therefore, owners have a significant influence and can be a major force behind their companies' policies for embedding SDGs into their strategic planning processes and implementation. In theory, from the firm's financial perspective, complying with SDGs may come at the expense of lower financial returns for the shareholders or owners. Therefore, adopting SDGs could result in a transfer of wealth from shareholders to other stakeholders [11].

Related to SDGs, there has also been increased focus on environmental, social, and governance (ESG) criteria that enable organizations to assess sustainability and ethical practices while harnessing the benefits of financial performance [12,13]. Still, the United Nations acknowledges that progress on the SDG agenda is too slow [14].

How can the change be accelerated? Schoon and Cox [15] highlight the importance of collaboration in governance for sustainability, and Van Tulder [16] emphasizes the ability for related stakeholders to collectively work together towards a common vision, thus determining the effectiveness of chosen interactions or interventions. Collaboration being important in governance for sustainability and an opportunity for related stakeholders to work together, we found a gap in analyzing collective action with the connection between ESG and SDGs. We addressed this gap and explored whether collective action can be solidified through an ownership strategy, thereby accelerating change and facilitating stakeholder alignment through collaboration and collective action.

An ownership strategy is a novel governance mechanism for responsible ownership and collective action by owners, fostering improvements in corporate governance [17]. It is a collaboration pact between owners that clearly expresses their wills and roles in promoting the long-term strategic focus, while at the same time acting as a guide to the board of directors to prioritize cooperation to deliver on the company's goals and objectives $[17,18]$. Following lines of social scientific research exploring how humans work together to resolve collective action dilemmas [19], we addressed the call of Young [20] for a new type of governance during periods of transformation, detailing the importance of and the need for collaboration and coordination.

Building on the notion that responsible ownership via an ownership strategy leads to a sense of collective action and that collective action advances SDGs and ESG, our research question was born out of trying to determine whether a virtuous cycle could be created. As such, the research question was "How can responsible ownership aid in the issuing of green bonds?" We built on reinforcing cycles of collaboration and collaboration emphasis, focusing on cohesive governance teams. As part of this research, we turned to the financial literature wherein researchers are evaluating how green bonds can improve ESG ratings [21]. We therefore feel it is important to understand how responsible ownership can aid in the issuing of green bonds, and how it continues to be relevant in times of a worldwide pandemic.

In addressing the research, we present an empirical examination of governance in local-level sustainability transition [22] in the resolution of collective action dilemmas and improved agency. We applied a single-case research design from Reykjavik Energy (Orkuveita Reykjavíkur, Reykjavík, Iceland), an Icelandic energy and utility company, and used it to specifically look at the linkages between ownership strategy, SDGs, ESG, and green bond issuance. Following a near bankruptcy in the years following the 2008 financial crisis, Reykjavik Energy formulated an ownership strategy that became an important part of the company's resuscitation, along with an extensive financial rescue plan. Later, the company laid out relevant targets under the UN's SDGs as well as an ESG methodology. In 2019, the company issued green bonds for the first time, which reflected the company's mission of placing respect for the environment on equal footing with profits. The green bonds received the highest possible rating — a "dark shade of green" - from the independent body CICERO (Center for International Climate Research, Oslo, Norway). Reykjavik Energy followed 
up with a second green bond in 2020 and, heading into 2021, the company's situation is markedly different from that in the years leading up to and after the 2008 financial crisis; it is considered to be an international example for simultaneously delivering financial value to its three owners (three separate municipal governments) and essential services to constituents while striving for complete environmental sustainability.

The remainder of this article is structured as follows. First, attention is turned to a literature review of current developments in ownership, governance, SDGs, ESG, and green bonds. We then develop the research question that guided the study of how an ownership strategy can result in a green bond. In Section 3, we move on to a description of the research method and data, followed by Section 4, where we present the findings from the study. In the fifth and last section, we turn to our conclusion and discussion, followed by suggestions for future research.

\section{Literature Review}

\subsection{Ownership Strategy and the Governance Model}

Ownership strategy differs from general notions of strategy since it is not a definite plan of action [23]. Ownership strategy is also different from a shareholder (or partnership) agreement. It is not legal in nature, but rather a voluntary addition to the governance bundle. It is a collaboration pact between owners that represents their responsible ownership: their ownership commitment $[24,25]$ and the collective actions taken by the owners. An ownership strategy expresses the owners' wills and long-term visions, while at the same time acting as a guide to their representatives on the board of directors [17,18], supporting the effective board decision making that is crucial to good governance [26] as a substitute for traditional shareholder proposals, which have been viewed as an ineffective governance mechanism [27]. We envision owners (shareholders) as insider activists who possess valuable knowledge of the informal social structures, prevailing values and culture, and organizational routines of their companies. Such insider knowledge is particularly useful in building pressure on companies to be more socially and environmentally responsible [28] Through ownership strategy, insider activists can gain access to knowledge about the company's current leadership style, values, and political coalitions that indicate support or resistance to the activists' goals.

In this sense, we are not tying owners strictly to shareholder value thinking, where the purpose of companies is to "maximize shareholder value". There is a popular but perhaps misleading idea that describes shareholders as owners; however, there is a growing body of research indicating that shareholders are not necessarily the "owners" of the companies [29]. Shareholders do not own companies-they own "stock" and, as owners of such stock, their rights are limited. Sikka and Stittle [30] have called to abandon the shareholder model of governance while boosting stakeholder empowerment for the long-term wellbeing of corporations. As noted above, the ownership strategy serves as a collaboration pact between owners, while giving a clear message to the board of directors that sharpens their mandate. While seeking to solve the lack of an unambiguous ownership mandate and the possible resulting managerial failure, an ownership strategy guides the firm's governance and lays the foundation for a sustainable future $[17,31]$.

Challenges and transformation following global challenges such as financial crises have distorted organizational business models [32]. Since the 2008 financial crisis, corporate governance literature has increasingly focused on the increased engagement of ownership (sometimes referred to as active or responsible ownership). The measures taken to encourage and foster responsible ownership differ. Bolton and Samama [33] introduced the idea of loyalty shares, which promise benefits to shareholders if they hold on to their ownership for a specified period. The idea is to encourage owners to become more favorable towards long-term value creation and, as a result, long-term ownership. On the other hand, Mayer $[24,25]$ promotes committed ownership and advocates that companies should be held accountable to a higher purpose than shareholder value maximization. The latter concept is closely related to the theory of the economics of higher purpose by Thakor and 
Quinn $[34,35]$. Hart and Zingales [36] also argue that maximization of shareholder welfare is not the same as shareholder value maximization. They propose that company and asset managers should pursue policies consistent with investor preferences. The commonalities of these contributions lie in their attempts to curb the potentially dangerous forces of managerialism and the dominance of short-term financial interest at the expense of healthy longevity and good stakeholder relations. Collective action by owners is an element of responsible ownership that an ownership strategy serves to establish.

Specific owner identities such as families [37] and industrial foundations [38] conduct their ownership with patience and a sense of responsibility. One potential reason for this is that these particular owners tend to either be singular or majority owners [39]. It is less clear what happens when different owners must coordinate their actions. While there seems to be momentum as far as institutional investors' shareholder duties go, as shown by the amendments to the European Union's 2007 Shareholder Rights Directive (adopted in 2017), practitioners and politicians are more hesitant when it comes to coordinating with other shareholders. This may be because it is considered to be interference with their property rights (in this respect, institutional investors are indeed different in that they are merely financial intermediaries with long-term obligations towards their constituency). The existing research on state-owned enterprises (SOEs) recognizes that an SOE's chief goal is something other than maximizing profit, such as increasing commitment or complying with corporate social responsibility (CSR)/ESG criteria [40-42]. These organizations are expected to present a level of social and environmental responsibility that goes beyond profit seeking [43] because their main function is not to obtain higher returns, but to facilitate public policy objectives [44]. The issues that most SOE managers associate with CSR mainly concern a generally accepted body of goals and means for sustainable development: ethics and corporate transparency, the contribution to economic development and wealth distribution, social action, dialogue with stakeholders, environmental management, and the voluntary integration of responsible criteria into company strategy [40]. Furthermore, the managers of these SOEs consider that the adoption of CSR and/or ESG policies could enhance the organization's image and reputation and bring it greater legitimacy in the performance of public actions. Building on the notion of companies being held accountable to a higher purpose than shareholder value maximization, we turn our attention to long-term sustainability.

\subsection{SDGs and Linkages to Environmental, Society and Governance (ESG)}

In 2015, the United Nations released the SDGs as a part of their 2030 Agenda for Sustainable Development [1]. The SDGs are a set of 17 goals with 169 targets that seek to build upon the Millennium Development Goals from 2000. The SDGs aim to be a "blueprint to achieve a better and more sustainable future for all" [1]. Joshi, Hughes, and Sisk [45] provided a conceptualization of SDG governance while arguing that "virtuous feedback loops" could cause improvements in human wellbeing, the environment, the economy, and governance. Persson, Weitz, and Nilsson [46] explored how countries are both aligning to and internalizing the goals, and applied principal-agent theory to suggest that behavior-based reporting could be emphasized alongside outcome-based reporting; they suggest three main priorities: social awareness, defining national targets in order to focus the implementation, and action-based reporting at the national and subnational levels. Biermann et al. [2] considered a novel type of global governance that includes adapting goal setting in the context of national circumstances, ensuring integration into policies that avoid negative trade-offs and create positive synergies, and improving governance mechanisms to changing conditions such as changes in technology and science.

Bowen et al. [3] furthered the understanding of implementing SDGs by examining three main governance challenges-cultivating collective action, making difficult trade-offs, and ensuring accountability - while considering the linkages between the three challenges, using examples such as the "free rider" problem. Van Zanten and Van Tulder [4] looked specifically at how companies could conceptualize SDGs within business strategies and 
identified areas for further research, such as the exploration of in-depth case studies of companies that have integrated SDGs into their internal planning.

While there appears to be an intuitive connection between SDGs and ESG, the research on ESG has typically focused on the motivation of a firm and its managers to adopt an ESG framework [12,47,48], as well as the formation, adoption, and disclosure of ESG measurements. Perhaps not surprisingly, a number of studies have investigated the financial performance of companies adopting an ESG framework; in studying U.S. companies, Greenwald [49] found that companies with stronger ESG scores beat earnings estimates more often than companies with lower ESG scores. On a broader level, Friede, Busch, and Bassen [50] summarized approximately 2200 individual studies analyzing the connection between ESG criteria and corporate financial performance (CFP), and found that a large majority of the studies reported positive findings, with financial performance appearing to be stable over time. Ortas et al. [13] conducted an empirical analysis of companies who were committed to the United Nations Global Compact, a year 2000 initiative to encourage businesses to implement sustainable principles, and found that companies saw improvements in their ESG performance. We believe that there is a gap in the analysis of collective action in governance for sustainability through the connection between ESG and SDGs and how such action can lead to other positive outcomes for the firm. We turn next to linkages to green bond financing.

\subsection{Linkages to Green Bond Financing}

Bondholders do not have voting power, so sustainability could be considered a less relevant issue for bonds than for equity. Nevertheless, recent research [51] indicates that an ESG rating is a matter of concern for corporate bond investors, since it could affect the business' performance and its future continuity. A recent example is Volkswagen's "dieselgate" scandal in 2015; once the scandal was revealed, the spread of Volkswagen's credit default swaps (CDSs), which measure the default risk on bonds, rose from 76 to 300 basis points (bps) [52].

Recent research evidence has confirmed lower spreads and better pricing of corporate bonds as a result of strong ESG performance $[53,54]$. In particular, the environmental component of an ESG tends to be increasingly relevant for corporate bonds [55,56]. Recent theoretical and empirical studies seem to confirm the idea that companies with a stronger specific governance mechanism (ownership structure) could benefit from a lower cost of debt $[57,58]$. From a credit rating point of view, the view of scholars is that major rating agencies consider ESG risks and opportunities in their assessment of a firm's overall risks; moreover, firms with stronger ESG performances could increase the attractiveness of their bonds, reducing the cost of their debt $[59,60]$.

Green bonds are a relatively new financing construct having emerged in the early 2010s. Within green bond research, much attention is paid to the pricing of green bonds and how they affect the cost of capital, as well as to the reception of green bonds by investors and publicly traded markets [21,61-64]. The overall results of Flammer's [65] (p. 5) study suggest that green bonds "contribute to both financial and environmental performance, but only when they are certified." Maltais and Nykvist [66] studied additional factors including how green bonds influence sustainability within a company. Despite the abundance of research on green bonds, studies that link green bonds to a firm's governance as a result of responsible ownership are lacking. The question thus becomes: How can responsible ownership aid in the issuing of green bonds? We turn next to describing the method used in the empirical study to answer the research question.

\section{Research Design, Materials and Methods}

\subsection{Methodological Approach}

Given the focus of this empirical study, the work rested mainly on a qualitative method to gain an understanding of underlying reasons, motivations, and opinions [67]. Qualitative data allowed us as researchers to explore and hypothesize by getting close to 
participants and settings to examine relationships $[68,69]$. Additionally, we utilized the power of a single-case research design [69] and purposefully selected an information-rich case [70]. We believe that this research method is particularly useful, since we wanted to uncover emerging trends in the thinking on the subject. Furthermore, we wanted to answer calls for in-depth qualitative studies of corporate governance [71] and, while qualitative studies within governance have grown in number, they remain a fraction of published work in scholarly journals [72]. Additionally, some elements of the descriptive quantitative method were used, relying upon the company's financial information. This study used a two-fold empirical methodology: the study of archival data and qualitative case work within the case company, allowing for in-depth understanding of the subject matter [73]. Data collection included semi-structured, open-ended interviews and archival documentary analysis [74]. In collecting different sources of data, the aim was to obtain a thorough understanding of the subject matter while allowing for data triangulation [75]. The process was iterative; data collection and initial analysis occurred simultaneously.

\subsection{Institutional Context and Case Selection}

In addressing the research question, we used a case-based approach. Since single case studies can richly describe the existence of a phenomenon [69], this case was selected because of its suitability for illuminating and extending relationships as well as logic among constructs [76]. We used purposeful sampling, a technique widely used in qualitative research for the identification and selection of information-rich cases [77]. This involved the identification and selection of a case containing the desired subject, combined with the company's availability and interest to participate [77]. After informed consent was gathered from the company's CEO, all researchers were introduced along with their backgrounds and affiliations. Along with the consent to use company data for a case-based analysis, consent from all interviewees was gathered via email and confirmed in the interviews.

The case company, Reykjavik Energy, dates back to 1909, although its modern formation occurred in 2000 when three different utility companies merged. The company now provides electricity, fiber optic networking, heating, water, and sewage services across southwestern Iceland, where more than two thirds of the country's population live. The company enjoys unique access to geothermal energy, allowing it to provide electricity and water services at a low cost when compared with other Nordic nations. The ownership of the merged entity is held by three municipalities: Reykjavik (93.5\%), Akranes (5.5\%), and Borgarbyggd (1\%). A major change to the company's structure occurred in 2014 when it unbundled its electricity generation and distribution due to mandatory legislation. An ownership strategy was formed and put in effect in 2012, and has since guided the company's governance. In order to show how the company's reinforcing virtuous cycle has changed over time, we used Casadesus-Masanell and Ricart's [78] business models concept of "choices" (policies, assets, and governance) and "consequences" (flexible or rigid).

\subsection{Data Collection and Analysis}

Data were gathered in an established systematic fashion that enabled us to answer the stated research question. Data collection took place from September 2019 to November 2020. Archival data were gathered during the first month and nine interviews were conducted in October 2019, with follow-up and additional interviews in October 2020 and November 2020. Initial data analysis began alongside observations and data collection. A further description of data collection and sources follows:

1. All researchers were involved in in gathering archival data: primary data from inhouse sources and secondary data from the Internet and publicly available databases. Prior to commencing the interviews, we made notes on key case questions and requested specific documents. We collected and reviewed articles in the mainstream and business press in both English and Icelandic and accessed company documents including the ownership strategy, annual reports, sustainability reports, and financial data. Primary data included in-house data such as reports on the compliance to 
ownership strategy, data from SDG workshops held by the case company, information on green bonds, and quality handbook data that pertain to ownership strategy and its implementation. Secondary data were accessible via the Internet or publicly available databases such as Factiva.

2. Moving from archival data, which all researchers were involved in analyzing, a semi-structured, open-ended interview guide was developed and agreed upon by all researchers. The information from the archival data was reviewed and analyzed prior to the interviews and fed into the interview guide to focus questions for specific interviewees and minimize redundant questions on the ownership strategy. The formulation of interview questions was based on Becker's methodology [79], which advises asking how things happened, not why they happened. The questions were meant to probe and thereby gain a deeper understanding of the interviewees' answers, as per Eisendhardt and Graebner [76] as well as Yin [67]. The interviews were openended, although a central theme was given as a topic of discussion (e.g., company context, ownership strategy, SDGs, ESG, and green bonds), giving the respondents leeway in responding and the researchers a chance to probe interviewees' answers.

3. Together, the researchers chose a sample of interviewees. The sample of interviewees was chosen in a deliberate manner, namely a purposeful sample [67]. Interviewees were carefully selected with regard to their knowledge and first-hand experience with the subject. We were interested in interviewees' words and ideas, seeking a rich empirical description of the instances of the phenomena in question [67]. Interviewees were carefully selected based on consideration of their role and expected contribution to illuminating the subject.

4. Two researchers were involved in conducting interviews using the semi-structured, open-ended questionnaire from Step 2. Each interview lasted for about an hour, with majority of interviews directed by two researchers.

(a) The first round of interviews was conducted in October 2019 to gain a fuller understanding of the subject matter. Interviews were conducted at the Reykjavík Energy headquarters in Iceland. There were nine main respondents (see Table 1), holding either board, executive, or specialist positions within the company.

(b) The second round of interviews in October 2020 and November 2020 were conducted specifically to address owners and different stakeholders' view on the ownership strategy, SDGs, ESG, and green bonds. The respondents included one Reykjavik Energy executive (interviewed in the first round), the mayor of the City of Reykjavik (majority owner), and its former CFO, as well as seven Icelandic business leaders (see Table 1) from the stock exchange, banks, securities firm, and pension fund. The second round of interviews was conducted via video conferencing.

5. Interviews were transcribed onsite and within the day. Both researchers conducting the interviews transcribed onsite separately in order to ensure validity and reliability of the transcribed data.

6. Interview transcriptions were analyzed and manually coded by a third researcher.

Interviewing a total of eighteen respondents represents an approach to data collection that limited bias through the use of numerous and highly knowledgeable informants who viewed the subject matter from diverse perspectives [76].

Interviews were not recorded; interviewers made the most of active listening whilst taking detailed notes by computer, transcribing onsite. To handle or work through possible errors in transcription, we verified all interviews with two sets of notes, referring back to company documents and financial details as appropriate. Any doubts or inconsistencies in the notes between the two interviewers were verified by email with the interviewees. Notes from the interviews were analyzed simultaneously by a third researcher who was not involved in interviewing. 
Table 1. List of interviewees and interviews.

\begin{tabular}{|c|c|c|c|}
\hline 1st Round Interviewees & Type & Gender & Length of Interview \\
\hline CEO & In-Person & Male & $1.5 \mathrm{~h}$ \\
\hline $\mathrm{CFO}$ & In-Person & Male & $1.5 \mathrm{~h}$ \\
\hline Specialist Finance Treasury & Email & Female & $1.5 \mathrm{~h}$ (est.) \\
\hline VP Strategy and Governance & In-Person & Female & $2 \mathrm{~h}$ \\
\hline VP Communications & In-Person & Male & $1 \mathrm{~h}$ \\
\hline VP Environmental Affairs & In-Person & Female & $1 \mathrm{~h}$ \\
\hline VP Legal & In-Person & Female & $0.5 \mathrm{~h}$ \\
\hline Company Representative & In-Person & Female & $1 \mathrm{~h}$ \\
\hline Vice-Chairman, Board & In-Person & Male & $1 \mathrm{~h}$ \\
\hline \multicolumn{4}{|l|}{ 2nd Round Interviewees } \\
\hline VP of Private Equity of a listed bank & In-Person & Female & $1 \mathrm{~h}$ \\
\hline CEO of a stock exchange & In-Person & Male & $1 \mathrm{~h}$ \\
\hline COO of a pension fund & In-Person & Female & $1.5 \mathrm{~h}$ \\
\hline VP of Corporate Finance, securities firm & In-Person & Female & $0.5 \mathrm{~h}$ \\
\hline CEO of a software company within sustainability and ESG reporting & In-Person & Male & $1 \mathrm{~h}$ \\
\hline VP of Asset Management at a bank & In-Person & Female & $1.5 \mathrm{~h}$ \\
\hline Reykjavik Energy CFO & In-Person & Male & $1.5 \mathrm{~h}$ \\
\hline Portfolio Manager at a bank & In-Person & Female & $1 \mathrm{~h}$ \\
\hline Reykjavik Energy Owner-mayor Reykjavik & In-Person & Male & $1 \mathrm{~h}$ \\
\hline Reykjavik Energy Owner-former CFO Reykjavik & In-Person & Male & $1 \mathrm{~h}$ \\
\hline
\end{tabular}

Data were analyzed via grounded theory methodology, using manual coding wherein the text was ordered into meaningful themes. We found that we began to reach data saturation after the first round of nine interviews, as further distinct themes did not appear. The data were organized into informative themes such as governance (subthemes responsible ownership and collective action), sustainability (subthemes collaboration, ownership strategy, and business model) and funding (subthemes strategic decision making and green bonds). Below, Table 2 shows themes, subthemes, and how they connect to the literature, provide nuance, and extend existing theories.

The second round of nine interviews followed the same process of data analysis as the first round. The themes that emerged were the same as in the first round of interviews with the addition of the theme of challenges and subtheme of sustainability, providing nuance to the ideas of García-Sánchez et al. [32] on distortion in organizations' business models and shedding light on how green bonds can improve ESG ratings [21]. Also adding a factor to Maltais and Nykvist's [66] study on how green bonds influence sustainability at a company.

Analysis of all data was inductive and interpretive in order to arrive at a deeper understanding of how the company's ownership strategy was linked to SDGs, ESG, and the green bond issuance. This means that we did not enter the field in order to prove or disprove a hypothesis. Rather, we moved from specific observations, drawing a general conclusion based on the analysis, and developed a hypothesis for future research. For the purpose of triangulation and to limit bias, all four researchers were involved in the case study and interpretation of the empirical results. We turn next to the findings from the empirical case study in order to answer the research question. 
Table 2. Themes, subthemes, and how they connect to the literature, provide nuance, and extend existing theories.

\begin{tabular}{|c|c|c|}
\hline Theme & Subtheme & Informing \\
\hline \multirow{2}{*}{ Governance } & Responsible ownership & $\begin{array}{c}\text { Poteete et al. (2010) on how humans work together to resolve collective } \\
\text { action dilemmas. }\end{array}$ \\
\hline & Collective action & $\begin{array}{l}\text { Van Tulder (2018) on the ability for related stakeholders to collectively work } \\
\text { together towards a common vision, thus determining the effectiveness of chosen } \\
\text { interactions or interventions. }\end{array}$ \\
\hline \multirow{3}{*}{ Sustainability } & Collaboration & $\begin{array}{c}\text { Schoon and Cox (2018) in highlighting the importance of collaboration in } \\
\text { governance for sustainability. }\end{array}$ \\
\hline & Ownership strategy & $\begin{array}{l}\text { Young (2017) on new types of governance during periods of transformation, } \\
\text { detailing the importance of and the need for collaboration. }\end{array}$ \\
\hline & Business model & Valkering et al. (2017) on local-level sustainability transition. \\
\hline Funding & $\begin{array}{l}\text { Strategic decision making } \\
\text { Green bonds }\end{array}$ & $\begin{array}{l}\text { Forbes and Milliken (1999) on effective board decision making crucial to } \\
\text { good governance. }\end{array}$ \\
\hline Challenges & Sustainability & $\begin{array}{c}\text { García-Sánchez's et al. (2020) on ideas on distortion in organization's business } \\
\text { models following global challenges. } \\
\text { Tang \& Zhang (2018) on how green bonds can improve ESG ratings. } \\
\text { Maltais and Nykvist's (2020) on how green bonds influence sustainability at } \\
\text { a company. }\end{array}$ \\
\hline
\end{tabular}

\section{Results}

This section describes the single case study in which we illustrate the key elements of the company's history shaping its current governance and how it is linked to the SDGs, ESG and the issuance of green bonds. Below, we show different states of Reykjavik Energy's high-level business model representation utilizing Casadesus-Masanell and Ricart's [78] concepts of "choices" (policies, assets, and governance) and "consequences" (flexible and rigid). To start, in terms of policies and assets, Reykjavik Energy's business model involves a key "choice" to focus on geothermal energy and infrastructure primarily for generating and supplying electricity and hot water. Geothermal energy is widely acknowledged to have a low carbon footprint; the U.S. Energy Information Administration [80] states that geothermal plants produce $99 \%$ less carbon dioxide than similarly sized fossil fuel plants. In Reykjavik Energy's case, focusing largely on geothermal provides two important "consequences", which are the benefits of a minimal environmental footprint and of lowcost electricity and water (due to Iceland's abundant source of geothermal energy and the country's know-how and technology allowing it to be effectively harnessed). The dual benefit fosters economic growth and garners the support of constituents.

\subsection{From Responsible Ownership to the SDGs}

In 2008, the global financial crisis emerged and Iceland was hit particularly hard [81]; the economy went into a tailspin-the Icelandic krona lost half its value, the country's three major banks failed, and the political situation spiraled into turmoil. Reykjavík Energy faced near bankruptcy and extreme duress. There was substantial distrust between the company, the owners, and the general public, since the company had made questionable international investments unrelated to its core business and thrust itself into debt, with equity accounting for only $7 \%$ of overall liabilities and equity. Furthermore, the morale of employees was at an all-time low and the company lacked focus [31]. In addition to the company having strayed from its key focus on domestic geothermal energy (going so far as to invest in foreign geothermal operations and nonrelated businesses such as flax seed production and a tiger prawn farm), the external economic shock caused economic growth to falter and, as a result, the company's virtuous cycle eroded (see Figure 1 below). 


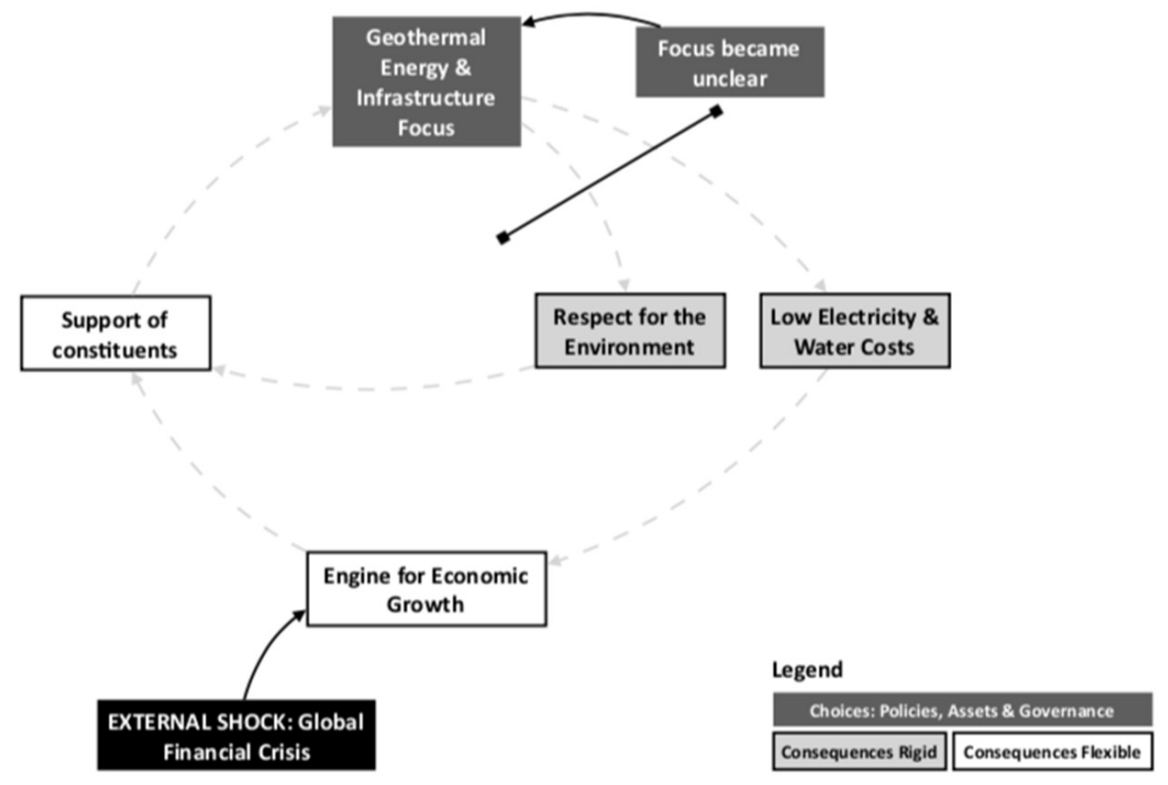

Figure 1. High-level Reykjavik Energy business model after economic shock.

With the company's position becoming unsustainable [31], the leadership reins were passed to a new CEO who assembled several new leaders in the company, including a new CFO. The new team, in close cooperation with the board and the owners, set to work fleshing out details of "The Plan", with the main emphasis of increasing cash flow and greater cost awareness within the company. In addition to the ardent focus on restoring the company to financial health, the new team also focused on changing the culture and created a goal of reaching gender parity and remove the gender pay gap. The new leadership instilled three main values: foresight, efficiency, and integrity. An ownership strategy became not only a major part of the company's resuscitation and extensive financial rescue plan, but also a rebuilding of trust with its owners and way to instill the new values. The CEO commented:

When I started there were six values and they had one thing in common-no one knew what they were! We changed this to three main values-foresight, efficiency, and integrity - that actually meant something. Everything we do must align to those values.

The ownership strategy is central to Reykjavik Energy's overall governance and represents responsible ownership and ownership commitment. As such, it sets out the mandate and roles of the company and the three owning municipalities [17]. The document [82] describes Reykjavik Energy's guiding vision, role in society, core activities, geographic area of operation, decision rights of the board of directors (e.g., dividend payments, policy decisions), financial objectives, operation risks, environment, and utilization of natural resources, terms of employment, communication and reporting, and decisions subject to owners' consent (new debt commitments in excess of $5 \%$ of the booked equity capital requires the owners' consent). Reykjavik Energy engages in strategic budgeting, incorporating decision making on measurable goals which are rooted in the ownership strategy. The importance of applying the ownership strategy to strategic decision making was described by one of the company's executives:

We use it to guide all our decision-making and it is a cornerstone of this company's governance.

While the ownership strategy is officially not legally binding, in practice, the board of directors reference the document to ensure that they are abiding by its terms [17] and apply it systematically to strategic decisions. Once introduced, the ownership strategy became a key governance "choice" that served to stabilize the company and reinforce its other key strategic "choices" on assets, policies, and governance. For example, assets are 
guided by the ownership strategy's clear boundaries on the company's role in society, core activities, and area of operation, limiting the company's investments to assets related to energy, electricity, water, and infrastructure. Similarly, the ownership strategy requires the review of key policies between the owners, board of directors, and management across stipulated categories such as dividends, investments, and the environment and natural resources, amongst others. Finally, governance is demonstrated by the ownership strategy itself as its own mechanism, as well as clauses within the document that govern the board of directors and the management of operational risks.

To summarize at a high level, we highlighted the most crucial "choices" of staying focused on domestic geothermal energy and infrastructure while deploying capital responsibly. Under the environment and natural resources guideline, the ownership strategy requires all endeavors to be developed in line with sustainable development criteria, which eventually led to the incorporation of the UN's Sustainable Development Goals (SDG) and an environmental, social, and governance (ESG) framework as we show below. Prior to the ownership strategy, there were no mechanisms to reinforce the company focus, responsible use of capital, or sustainable development criteria. That lack of reinforcement led to financial difficulties and the failure to consistently deliver the "consequences" of environmental benefit and low-cost electricity and water.

We can see evidence of the company's renewed focus on domestic geothermal energy and infrastructure in the post-crisis management team's decision to sell off and wind down any businesses that were unrelated to the core business of delivering local electricity, water services, and core infrastructure.

In a similar vein, evidence of the linkage to responsible use of capital is present in the ownership strategy's strict guideline of requiring owners' consent when new debt commitments exceeded $5 \%$ of booked equity capital. This is reflected in the company's Green Bond Framework [83], which states the following:

Operating an environmentally and socially sustainable business constitute the basis of $O R^{\prime}$ ' [RE] long-term strategy. Sustainable financing is a key part of the strategy and offers means to mobilize debt for environmental efforts.

Using the Green Bond Framework as an example, the owners' perspective comes through in the ownership strategy, representing their responsible ownership and collective action, directly affecting and guiding strategic decision making within Reykjavik Energy, as described by the mayor of the City of Reykjavik:

It provides a framework for strategic decision-making. It is a part of strategic corporate governance, so that the owners do not have to engage in some kind of a detailed management. Our will as owners is clear. If the board of directors assesses it such that the long-term vision is wrong or they wish to take the company in a different direction, then they need to ask for that mandate.

The City of Reykjavik's former CFO explained the owner's perspective in that: "Green Bonds are a natural continuation of what the Ownership Strategy stands for-emphasis on environment and sustainability." The Reykjavik mayor also iterated that while the ownership strategy positively affected trust between stakeholders, it was of importance that management acted and responded to challenges in accordance with it:

... [they] must be inclined to act and respond based on the Ownership Strategy and be true to it, otherwise trust might be diminished... Trust will not be built by statements but by actions.

To reinforce the sustainable development criteria required by the ownership strategy, Reykjavik Energy began to follow the international guidelines under the Global Reporting Initiative (GRI), with the goal of communicating social responsibility in a transparent manner in 2015. There were over 100 measures in the GRI which were broken down into the 10 categories: Strategy \& Analysis, Organizational Profile, Governance, Ethics \& Integrity, Economic, Environmental, Labor Practices \& Decent Work, Human Rights, Society, and Product Responsibility [84]. In 2017, the company made the decision to 
switch to a tighter set of measurements under the environmental, social, and governance (ESG) framework after meeting with executives at the NASDAQ Iceland Stock Exchange, who explained that Nordic and Baltic investors were interested in a condensed set of measurements. This was due in significant part to the GRI reporting being complicated in practice, as the VP of Communications reflected:

The GRI became a monster. We wanted to really allow a set of measures to answer a question: 'Are we socially responsible?' That's a big question and while we cannot answer it quickly, we wanted to open up the debate by showing accurate measurements along the dimensions of ESG.

A major influence in the company's ESG framework was the United Nations 17 Sustainable Development Goals (SDGs). In 2018, Reykjavik Energy began to report on the company's connections to the SDGs within the company's annual report [85]. The bulk of the company's 2018 annual report was dedicated to reporting on the company's 33 ESG measures and commenting on the United Nations 17 goals. While Reykjavik Energy followed the Nasdaq's ESG Reporting guidelines, it did not hire an external ESG rating agency such as Sustainalytics, Vigeo Eiris, or MSCI (Morgan Stanley Capital International). The VP of Environmental Affairs commented:

We have taken the time to ensure that we're accurately reflecting the UN measures in our reporting and how they connect to the ESG, which along with the Ownership Strategy, help to guide the environmental goals of what we want to achieve.

Reykjavík Energy has a strong governance ("G") component influenced by the ownership strategy, which in turn leads to the SDGs becoming embedded into policies. While the SDGs attempt to provide a world blueprint for sustainable development, companies find it difficult to make meaningful progress on all 17 SDGs due to the broad, all-encompassing nature of the goals. To help address this issue, the UN Global Compact published a practical guide for reporting, as well as emphasizing the need to prioritize SDGs to achieve maximum impact [86]. At Reykjavík Energy, the company conducted a series of internal and external stakeholder workshops to understand the company's operations and how actions could positively align to SDGs. The internal workshops were held specifically for managers and staff, while external workshops included different stakeholders throughout the company's ecosystem, such as representatives from the City of Reykjavík, associated consulting firms, representatives from heavy industries, and the Environment Agency of Iceland, among others. The results from these workshops with stakeholders are represented in Figure 2, showing that external and internal stakeholders emphasized four SDGs: "responsible consumption and production" along with "affordable clean energy", "climate action", and "clean water and sanitation".

An ever-increasing emphasis has been placed on SDGs and ESG to ensure the longevity of its operations. As the CEO of the company explained:

We must think 100 years ahead because we are providing underlying infrastructure for society. We must be very sure about where we are going.

In our view, we believe that the additional governance "choice" to have an ownership strategy created a "virtuous cycle" by reinforcing the other key "choices" in the company's business model of maintaining the focus on domestic geothermal energy and infrastructure, SDGs/ESG, and responsibly deploying capital. These "choices" work together to deliver a low environmental footprint and low-cost access to electricity and water. The company's "virtuous cycle" is shown in Figure 3. 


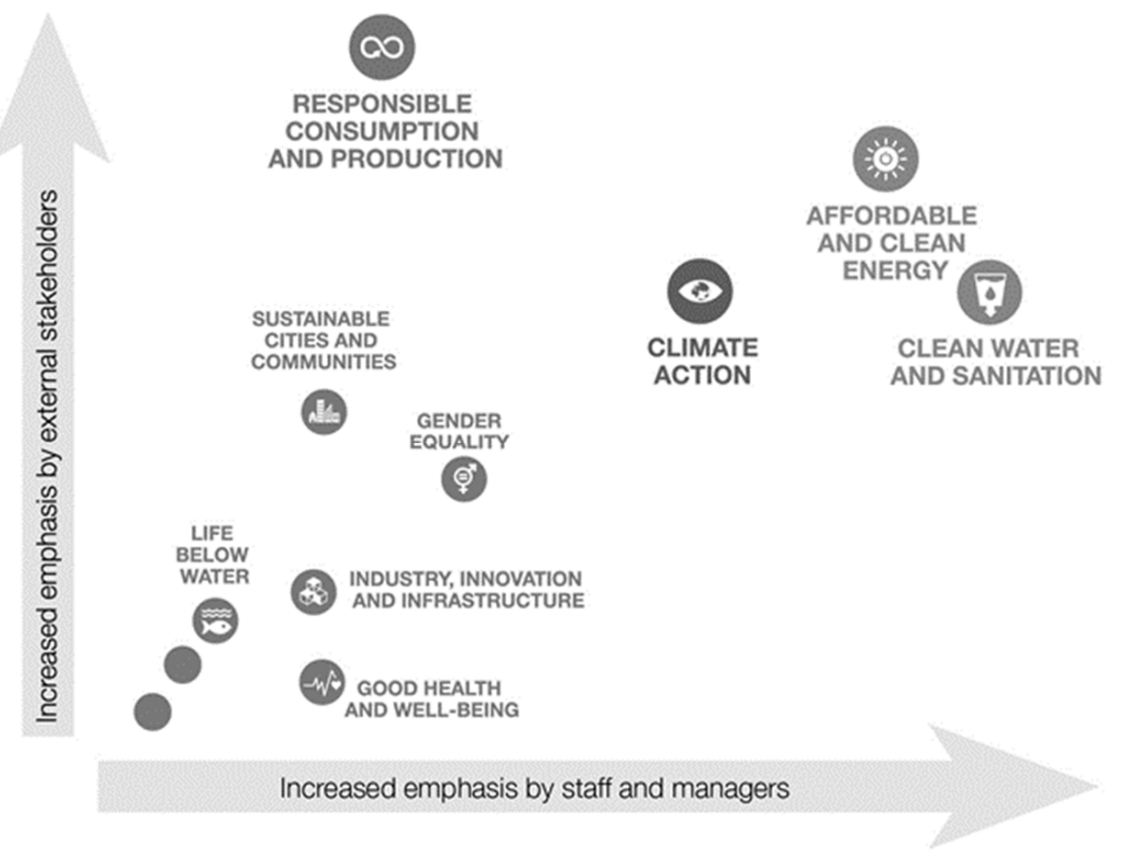

Figure 2. Materiality matrix and the results from the Reykjavik Energy workshops on the prioritization of the SDGs (Source: Reykjavik Energy, in-house data).

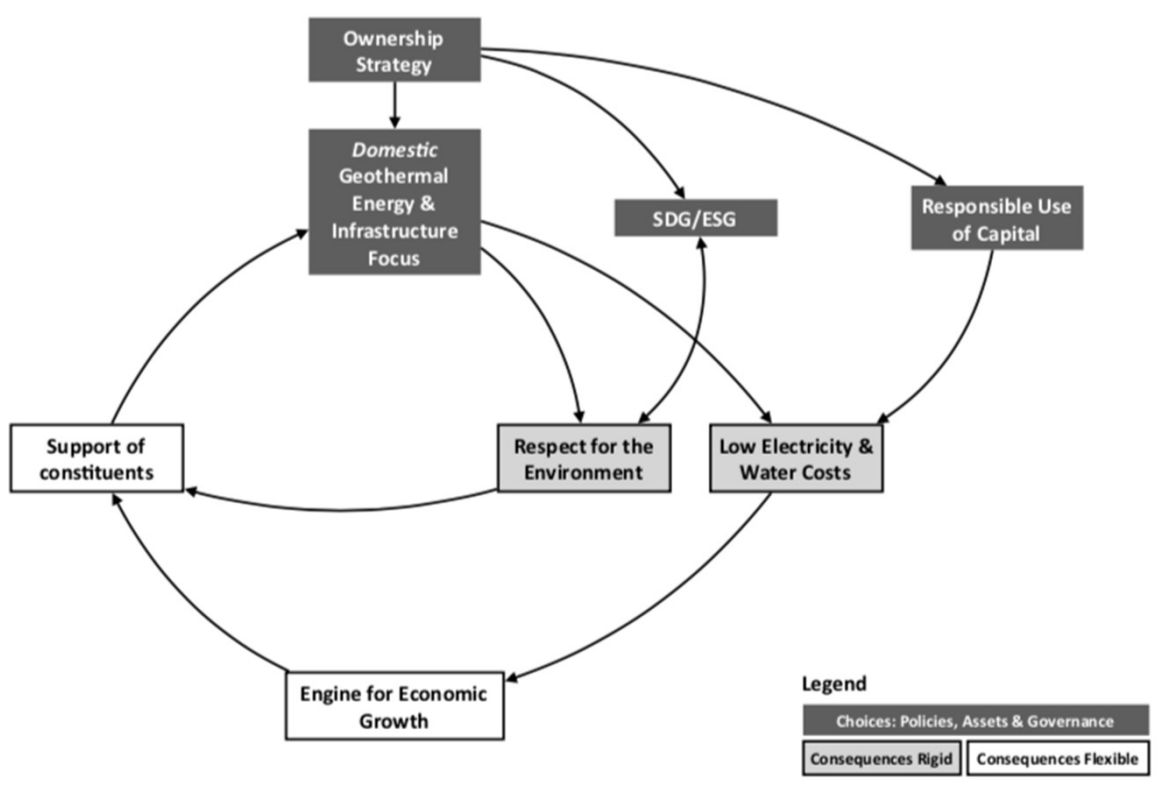

Figure 3. High-level Reykjavik Energy business model with ownership strategy.

As time went on, the need for financing that reflected the company's mission of placing respect for the environment on an equal footing with profits became increasingly apparent, and thus the notion of green bond issuance emerged.

\subsection{Funding and Green Bond Issuance}

During the period of 2009 to 2018, Reykjavik Energy's revenue grew by a compound annual growth rate (CAGR) of 5.8\% from ISK 26 billion (US $\$ 210$ million) to ISK 45.6 billion (US $\$ 380$ million), while EBITDA grew at a CAGR of $8.2 \%$ from ISK 13 billion (US \$105 million) to ISK 28.6 billion (US \$238 million) (Reykjavik Energy Consolidated Financial Statements 2014 and 2018). As of 2018, Reykjavik Energy's revenues derived from the following 
activities: electricity $(42 \%)$, hot water $(28 \%)$, cold water $(7 \%)$, sewer system $(12 \%)$, and other revenues $(12 \%)$.

In the 2018 fiscal year, the company had ISK 340.1 billion (US $\$ 2.9$ billion) in assets, of which $89 \%$ was property, plant, and equipment. On the other side of the balance sheet, equity accounted for $47 \%$ of the total, which many company executives felt was a key indicator of success, considering that a decade earlier it had been low as $7 \%$. Within liabilities, the current and noncurrent portion of bank borrowings represented $44 \%$ of the total balance sheet. The approximate average cost of debt was about $4 \%$ and the estimated weighted average cost of capital (WACC) was $8 \%$.

The idea to issue a green bond dated back to the autumn of 2018. Reykjavik Energy's CFO recounted the consideration to go with a green bond versus other types of financing:

Our financing primarily comes through bonds and banks. We had started to talk with the Nordic Investment Bank (NIB) as well as other partners in Sweden and realized they were ahead of us in thinking about sustainable investment. Within the finance area, we were quite inspired by our own Environmental VP and Reykjavik Energy's mindset and culture to balance financial and environmental factors in decision making. We knew the company was doing so many positive projects for the environment and we thought, 'why don't we be a part of it?

One of the other main drivers is the pricing of the green bonds. Pricing is important and this year we have put major efforts into reducing the premium Reykjavik Energy has to pay on benchmark bonds in the market, i.e., government bonds with similar maturity.

As a prerequisite to green bond issuance, Reykjavik Energy closely followed the International Capital Market Association's [87] Green Bond Principles, which define a green bond as "any type of bond instrument where the proceeds will be exclusively applied to finance or re-finance, in part or in full, new and/or existing eligible Green Projects and which are aligned with the four core components [of] use of proceeds, process for project evaluation and selection, management of proceeds and reporting." The use of proceeds was seen by the IMCA to be a "cornerstone" of the green bond framework and provided several examples of acceptable uses, such as renewable energy, energy efficiency, pollution prevention and control, and sustainable water and wastewater management, among others. The second component of having a clear selection process suggested that the issuer communicate its sustainability objectives and explain the project selection and eligibility criteria. The third component suggested that the company credit the net proceeds to a sub-account that is tracked in a transparent manner for investors to see the allocated and unallocated amounts. The final component dealt with effective reporting including the environmental impact of the projects.

Reykjavik Energy listed the bonds on the NASDAQ Iceland sustainable bond market and had originally planned on conducting an auction with Icelandic institutional investors in December 2018, but postponed the launch until February 2019. A specialist from the Finance Treasury area explained the timing consideration:

[We] postponed an auction in December 2018 to build up demand for the green bond. By doing this we believe we helped demand in the first green bond auction as investors had been "deprived" of the company's bonds for a few months. [We believe] this [was] crucial in the pricing of the bond and gave us the ability to be aggressive and strategic when it comes to deciding how much we wanted to issue and at what levels.

\subsection{Viewpoints from Owners and Business Leaders}

A series of interviews were conducted in October 2020 and November 2020 to address owners' and different stakeholders' views of the ownership strategy, SDGs, ESG, and green bonds, and several observations were made. First, the ownership strategy continues to be vital as a key governance mechanism, since it increases transparency and is one of the central reasons that Reykjavik Energy now has a good reputation and is able to continue 
advancing with SDGs/ESG and green bonds. The City of Reykjavik's mayor (the city being the company's majority owner) emphasized:

Ownership Strategy includes a strategy on dividend's policy, which includes information important to creditors. This has assisted us when issuing green bonds. It has created trust between the company and buyers of the bonds. I feel that the clear framework of Ownership Strategy has assisted us in establishing necessary trust with the financial market.

Reflecting on Reykjavik Energy's reputation, a VP of Private Equity of a listed bank said:

We favor a governance mechanism like an Ownership Strategy, as Reykjavik Energy has implemented, where we want a clear ownership structure and social responsibility at the highest levels ... Taking profit above purpose would not be following a sustainability strategy. We know that this crisis will be over soon, and if anything, it will divide those who truly follow purpose and those who do not, and we favor the prior.

Furthermore, a VP of Asset Management at a bank related the company's sustainability and governance to the success of issuing green bonds:

We believe its partially because of a very clear Ownership Strategy that impacts the governance structure positively, but as well because the companies seem to stick to its sustainability strategy.

Stressing the relationship between ownership strategy and green bonds, the City of Reykjavik's former CFO stated: The business must be green—enormously important—and the Ownership Strategy lays that out.

Second, the ownership strategy supports focus on sustainability and green bonds were considered to be a vital financing mechanism influencing sustainability at Reykjavik Energy. Green bonds are considered to be a vital financing mechanism, and some respondents pointed to a lack of supply of green bonds given the heavy demand. Reykjavik Energy has gained the market's attention through its emphasis on green bonds and managed to double its issuing and achieve cheaper financing by 50 basis points (bps). Reykjavik City's mayor commented:

Sustainability and Ownership Strategy of Reykjavik Energy are linked together. Our analysis shows that during just the last 5-10 years, investors have more and more searched investment opportunities within sustainability. It has become part of a required investment portfolio to include green investments. The initial idea of issuing a Green Bond was resting on getting a good financing plus increase our own investors' portfolio. Now we know that we have a solid group of investors who look towards green investment opportunities. We have a strong focus on sustainability, it is part of our corporate strategy and the Ownership Strategy reflects that. We believe that sustainability is a responsible strategy and a part of our Ownership Strategy which will only make ourselves more sought after as investment opportunity.

The interviewees seemed determined that the ownership strategy, SDG, ESG, and green bonds will continue to remain of utmost importance for Reykjavik Energy. Since the green bond forces a high level of reporting on the deployment of funds to environmental resources, a two-way reinforcement occurs between SDGs/ESG and the green bond. As such, the green bond provides an important additional reinforcing mechanism in the business model; specifically, it helps to strengthen the tie between SDGs/ESG and the responsible use of capital, as shown in Figure 4. 


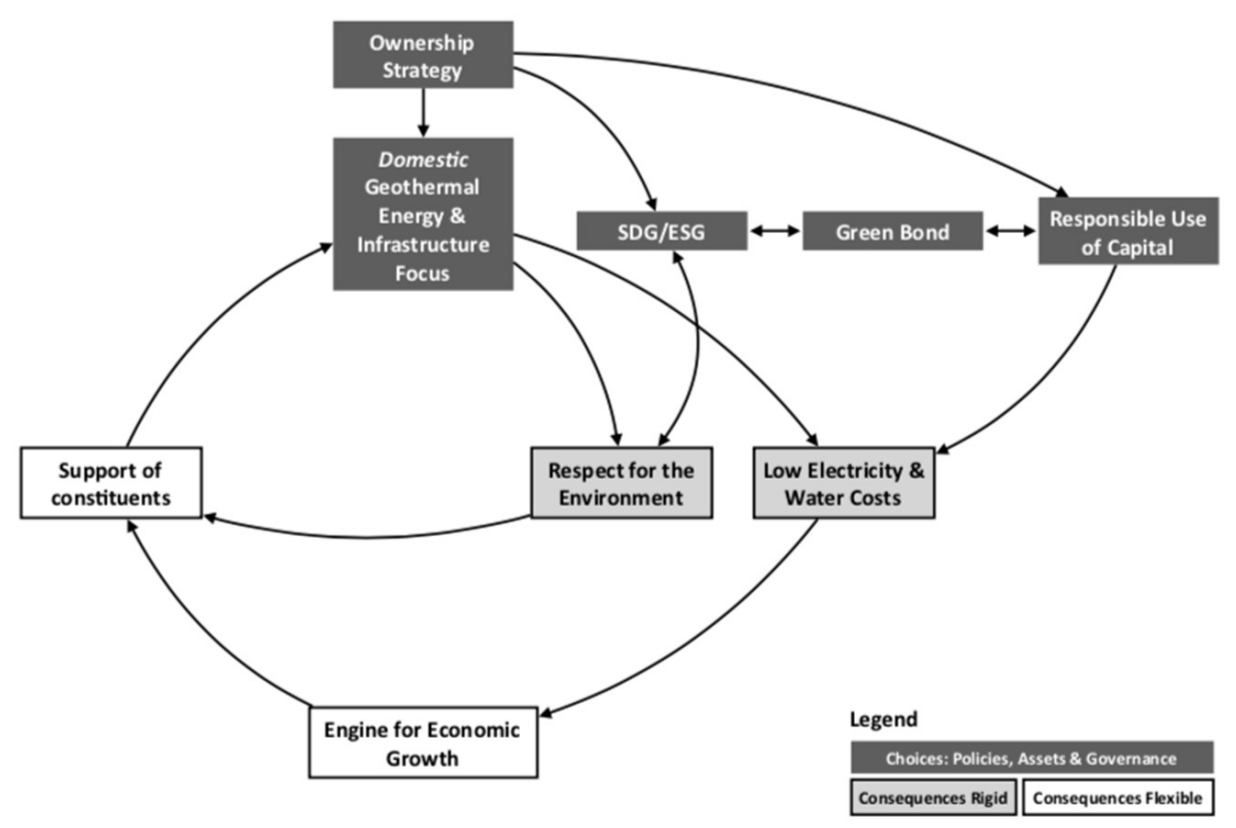

Figure 4. High-level Reykjavik Energy business model with green bonds.

We now turn to the conclusion and discussion.

\section{Conclusions and Discussion}

In this study, we have provided an empirical examination of governance in a locallevel sustainability transition [22] in the resolution of collective action dilemmas and improved agency. We have attempted to tie responsible ownership, collective action, SDGs, ESG, and green bonds together through the case-based empirical example of Reykjavik Energy, with the main research question being "How can responsible ownership aid in the issuing of green bonds?" We explored how responsible ownership and collective action can be solidified through an ownership strategy when owners and stakeholders are clear on their roles and purpose. Through an ownership strategy, insider activists [28] gain access to better knowledge of the company's current leadership style, values, and the coalitions that indicate support to activists' goals. We add to existing research on SOEs that has recognized their goals to be more than the "bottom line", such as increasing commitments in complying with CSR/ESG criteria [40-42]. Owners might often have different goals and objectives for the company, which tend to be formed by the time horizons of their investments [5-7]. We know that progress on SDGs has been slower than anticipated. Van Tulder's [16] call to accelerate change emphasizes the ability for related stakeholders to collectively work together towards a common vision, highlighting Schoon and Cox's [15] belief in the importance of collaboration in governance for sustainability.

We believe that the case company's collective action manifested itself in the adoption of SDGs and an ESG framework and, as we suggest, this might not have been possible without the ownership strategy explicitly outlining the dual pursuit of sustainability and profitability. We were influenced by Bryson's [88] concept of satisfying key stakeholders by their own definition of what is valuable; in the case of Reykjavik Energy, stakeholders include the customers of electricity and water services, all of whom, in one way or another, are constituents of the municipalities. Moreover, while the municipalities officially "own" the company, they must ultimately answer to the constituents who place tremendous value in obtaining those services without interruption and at inexpensive rates.

The ownership strategy's guiding vision summarizes the company's overall aim: "respecting the environment, responsible utilization of the natural resources and responsible utilization of capital." [82]. By utilizing Casadesus-Masanell and Ricart's [78] concepts of "choices" and "consequences" within business models, we demonstrated how the ownership strategy became an essential reinforcement of a virtuous cycle by creating 
linkages to focus on domestic geothermal energy and infrastructure, responsible use of capital, and maintenance of sustainable development criteria via SDGs and an ESG framework. The three choices all help the company to deliver on the commitment of "respecting the environment" while ensuring low-cost access to electricity and water.

However, we started to see the virtuous cycle really come alive with the introduction of the green bond. The green bond provides a less expensive option for financing while ensuring that capital is deployed to responsible projects. The cheaper financing allows the company to deliver a stronger return on capital through dividend payments to the municipal owners, while also enabling it to meet one of its main objectives in the ownership strategy: "Ensure service to its customers at reasonable and competitive prices." Since the green bond forces a high level of reporting on the deployment of funds to environmental resources, a two-way reinforcement occurs between SDGs/ESG and the green bond. As such, the green bond provides an important reinforcement between SDGs/ESG and the responsible use of capital.

Reykjavík Energy's owners, board, and management team all maintain that their first green bond would have not emerged as a possibility if it were not for the focus of the SDGs and ESG, which were made possible by the clarity of the ownership strategy. This was perhaps most evident when the City of Reykjavik's mayor explained how the ownership strategy was an essential building block of trust between the company and the financial market.

Our theoretical contribution comes from our addressing of a gap in the literature analyzing collective action in governance for sustainability through the connection between ESG and SDGs. We provide a case related to theory, exploring how ownership strategy becomes the starting point or "rallying call" for the collective action that can lead to strengthening virtuous cycles. This contribution explores connections to help accelerate companies' adoption of SDGs and ESG with tangible outcomes. Our practical contribution lies in the provision to companies of a thought-provoking case and a practical suggestion; companies wishing to further their SDG agenda with an increased focus on ESG frameworks as criteria enabling sustainability and ethical practices to be assessed and measured while harnessing benefits of financial performance should consider applying an ownership strategy.

This is an appealing outcome, but difficulties arise. The virtuous cycle might not be available for all companies. Limitations arise from the research design as well as the sample. While qualitative research can be generalized through abstraction, these results might not be applicable to different contexts, industries, and geographies. The case should serve as an introduction to the development of a theoretical model of the relationship between responsible ownership and the potential of companies implementing SDGs and an ESG framework.

Furthermore, we acknowledge that another external shock could put pressure on economic growth, which could, over time, prove to lessen the strength of the virtuous cycle. However, for the purpose of this study, the aim was to explore connections to help accelerate companies' adoption of SDGs and ESG with tangible outcomes (i.e., lower financing costs through a green bond). We hypothesize that responsible ownership and collective actions by owners represented in an ownership strategy that clearly lays out its objectives when it comes to the dual pursuit of sustainability and profits can lead to positive outcomes such as green bond issuance and the responsible use of capital. Thus, the foundational elements of the ownership strategy are reinforced. We encourage future comparative studies and investigation demonstrating tangible results of an ownership strategy and further research to test our hypothesis.

Author Contributions: Conceptualization and methodology, G.E.J. and T.O.S.; validation, A.R.A. and J.M.; formal analysis, G.E.J. and T.O.S.; investigation, J.M. and T.O.S.; writing-review and editing, G.E.J. and J.M.; visualization, J.M.; supervision, T.O.S. and A.R.A.; All authors have read and agreed to the published version of the manuscript. 
Funding: This research received no external funding.

Institutional Review Board Statement: Not applicable.

Informed Consent Statement: Not applicable.

Data Availability Statement: Not applicable.

Conflicts of Interest: Corresponding author is an industrial $\mathrm{PhD}$ fellow employed by the case company. The company had no role in the design of the study; in the collection, analyses, or interpretation of data.

\section{References}

1. United Nations. Transforming Our World: The 2030 Agenda for Sustainable Development. UN Report. $2015 . \quad$ Available online: https://sustainabledevelopment.un.org/content/documents/21252030\%20Agenda\%20for\%20Sustainable\%20 Development\%20web.pdf (accessed on 13 April 2020).

2. Biermann, F.; Kanie, N.; Kim, R.E. Global Governance by Goal-Setting: The Novel Approach of the UN Sustainable Development Goals. Curr. Opin. Environ. Sustain. 2017, 26-27, 26-31. [CrossRef]

3. Bowen, K.J.; Cradock-Henry, N.A.; Koch, F.; Patterson, J.; Häyhä, T.; Vogt, J.; Barbi, F. Implementing the “Sustainable Development Goals": Towards addressing three key governance challenges-collective action, trade-offs, and accountability. Curr. Opin. Environ. Sustain. 2017, 26-27, 90-96. [CrossRef]

4. Van Zanten, J.A.; Van Tulder, R. Multinational Enterprises and the Sustainable Development Goals: An Institutional Approach to Corporate Engagement. J. Int. Bus. Policy 2018, 1, 208-233. [CrossRef]

5. Bacon, N.; Wright, M.; Ball, R.; Meuleman, M. Private Equity, HRM, and employment. Acad. Manag. Perspect. 2013, 27, 7-21. [CrossRef]

6. Bushee, B. Identifying and attracting the 'right' investors: Evidence on the behaviour of institutional investors. J. Appl. Corp. Financ. 2004, 26, 28-35. [CrossRef]

7. Hoskisson, R.E.; Hitt, M.A.; Johnson, R.A.; Grossman, W. Conflicting voices: The effects of institutional ownership heterogeneity and internal governance on corporate innovation strategies. Acad. Manag. J. 2017, 45, 697-716. [CrossRef]

8. Miller, D.; Wright, M.; Le Breton-Miller, I.; Scholes, L. Resources and innovation in family businesses: The Janus-face of socioemotional preferences. Calif. Manag. Rev. 2015, 58, 20-40. [CrossRef]

9. Villalonga, B. Growing, Financing, and Managing Family and Closely Held Firms: Overview of the Course; Harvard Business School: Cambridge, MA, USA, 2009.

10. Villalonga, B.; Amit, R. How are U.S. family firms controlled? Rev. Financ. Stud. 2009, 22, 3047-3091. [CrossRef]

11. Villalonga, B. The impact of ownership on building sustainable and responsible businesses. J. Br. Acad. 2018, 6, 375-403. [CrossRef]

12. Gillan, S.; Hartzell, J.; Koch, A.; Starks, L. Firms' environmental, social and governance (ESG) choices, performance and managerial motivation. Working Paper. 2010.

13. Ortas, E.; Álvarez, I.; Garayar, A. The Environmental, Social, Governance, and Financial Performance Effects on Companies that Adopt the United Nations Global Compact. Sustainability 2015, 7, 1932-1956. [CrossRef]

14. United Nations. Report of the Secretary-General on SDG Progress 2019. UN Report. 2019. Available online: https:// sustainabledevelopment.un.org/content/documents/24978Report_of_the_SG_on_SDG_Progress_2019.pdf (accessed on 13 April 2020).

15. Schoon, M.; Cox, M.E. Collaboration, Adaptation, and Scaling: Perspectives on Environmental Governance for Sustainability. Sustainability 2018, 10, 679. [CrossRef]

16. Van Tulder, R. Business \& The Sustainable Development Goals: A Framework for Effective Corporate Involvement; Erasmus University: Rotterdam, The Netherlands, 2018.

17. Jonsdottir, G.E.; Sigurjonsson, T.O.; Poulsen, T. Ownership Strategy: A Governance Mechanism for Collective Action and Responsible Ownership. Corp. Ownersh. Control 2020, 17, 34-45. [CrossRef]

18. Wahl, M.F. Strategic Audit and Ownership Strategy. Int. J. Bus. Soc. Res. 2015, 5, 93-100. [CrossRef]

19. Poteete, A.R.; Janssen, M.A.; Ostrom, E. Working Together: Collective Action, the Commons, and Multiple Methods in Practice; Princeton University Press: Princeton, NJ, USA, 2010.

20. Young, O.R. Beyond Regulation: Innovative Strategies for Governing Large Complex Systems. Sustainability 2017, 9, 938. [CrossRef]

21. Tang, D.Y.; Zhang, Y. Do shareholders benefit from green bonds? J. Corp. Financ. 2018. [CrossRef]

22. Valkering, P.; Yücel, G.; Gebetsroither-Geringer, E.; Markvica, K.; Meynaerts, E.; Frantzeskaki, N. Accelerating Transition Dynamics in City Regions: A Qualitative Modeling Perspective. Sustainability 2017, 9, 1254. [CrossRef]

23. Mintzberg, H.; Waters, J.A. Of Strategies, Deliberate and Emergent. Strateg. Manag. J. 1985, 6, 257-272. [CrossRef]

24. Mayer, C. Firm Commitment; Oxford University Press: Oxford, UK, 2013.

25. Mayer, C. Prosperity; Oxford University Press: Oxford, UK, 2018.

26. Forbes, D.P.; Milliken, F.J. Cognition and Corporate Governance: Understanding Boards of Directors as Strategic Decision-Making Groups. Acad. Manag. Rev. 1999, 24, 489-505. [CrossRef] 
27. Ertimur, Y.; Ferri, F.; Stubben, S.R. Board of directors' responsiveness to shareholders: Evidence from shareholder proposals. J. Corp. Financ. 2010, 16, 53-72. [CrossRef]

28. Briscoe, F.; Gupta, A. Social Activism in and around Organizations. Acad. Manag. Ann. 2016, 10, 671-727. [CrossRef]

29. Stout, L. The Shareholder Value Myth: How Putting Shareholders First Harms Investors, Corporations, and the Public; Berrett Keohler: San Francisco, CA, USA, 2012.

30. Sikka, P.; Stittle, J. Debunking the myth of shareholder ownership of companies: Some implications for corporate governance and financial reporting. Crit. Perspect. Account. 2019, 63. [CrossRef]

31. Jonsdottir, G.E. A question of trust: The story of Reykjavík Energy. In The Return of Trust? Institutions and the Public after a Crisis; Sigurjonsson, T.O., Bryant, M., Schwarzkopf, D., Eds.; Emerald Publishing: Bingley, UK, 2018.

32. García-Sánchez, I.-M.; Raimo, N.; Marrone, A.; Vitolla, F. How Does Integrated Reporting Change in Light of COVID-19? A Revisiting of the Content of the Integrated Reports. Sustainability 2020, 12, 7605. [CrossRef]

33. Bolton, P.; Samama, F. Loyalty shares: Rewarding long-term investors. J. Appl. Corp. Financ. 2013, 25, 86-97. [CrossRef]

34. Thakor, A.V.; Quinn, R.E. The economics of higher purpose. ECGI Financ. Work. Paper 2013, 395. [CrossRef]

35. Thakor, A.V.; Quinn, R.E. Creating a purpose-driven organization. Harv. Bus. Rev. 2018, 96, 78-85.

36. Hart, O.; Zingales, L. Companies should maximize shareholder welfare not market value. J. Law Financ. Account. 2017, 2, 247-275. [CrossRef]

37. Asaba, S. Patient investment of family firms in the Japanese electric machinery industry. Asia Pac. J. Manag. 2013, 30, 697-715. [CrossRef]

38. Thomsen, S.; Poulsen, T.; Børsting, C.; Kuhn, J. Industrial foundations as long-term owners. Corp. Gov. Int. Rev. 2018, 26, 180-196. [CrossRef]

39. Faigen, B.; Mygind, N.; Sigurjonsson, T.O.; Arnardottir, A.A. Three dimensions of employees acquiring shares in their firms: Personal characteristics, motives and type of ownership. Econ. Ind. Democr. 2018. [CrossRef]

40. Bolívar, M.P.R.; Sánchez, R.G.; Hernández, A.M.L. Managers as drivers of CSR in state-owned enterprises. J. Environ. Plan. Manag. 2015, 58, 777-801. [CrossRef]

41. Bruton, G.D.; Peng, M.W.; Ahlstrom, D.; Stan, C.; Xu, K. State-owned enterprises around the world as hybrid organizations. Acad. Manag. Perspect. 2015, 29, 92-114. [CrossRef]

42. Zhao, M. CSR-Based Political Legitimacy Strategy: Managing the State by Doing Good in China and Russia. J. Bus. Ethics 2012, 111, 439-460. [CrossRef]

43. Russo, A.; Perrini, F. Investigating Stakeholder Theory and Social Capital; CSR in Large Firms and SMEs. J. Bus. Ethics 2010, 91, 207-221. [CrossRef]

44. Cunningham, M. State-owned Enterprises: Pursuing Responsibility in Corporate Social Responsibility. Manag. Commun. Q. 2011, 25, 718-724. [CrossRef]

45. Joshi, D.K.; Hughes, B.B.; Sisk, T.D. Improving governance for the post-2015 Sustainable Development Goals: Scenario forecasting the next 50 years. World Dev. 2015, 70, 286-302. [CrossRef]

46. Persson, Å.; Weitz, N.; Nilsson, M. Follow-up and Review of the Sustainable Development Goals: Alignment vs. Internalization. Rev. Eur. Comp. Int. Environ. Law (Reciel) 2016, 25, 59-68. [CrossRef]

47. Kocmanová, A.; Šimberová, I. Determination of Environmental, Social and Corporate Governance Indicators: Framework in the Measurement of Sustainable Performance. J. Bus. Econ. Manag. 2014, 15, 1017-1033. [CrossRef]

48. Syed, A.M. Environment, social, and governance (ESG) criteria and preference of managers. Cogent Bus. Manag. 2017, 4, 1340820. [CrossRef]

49. Greenwald, C. ASSET4: ESG and Earnings Performance; Thomson Reuters: New York, NY, USA, $2010 . \quad$ Available online: https://www.thomsonreuters.com/content/dam/openweb/documents/pdf/tr-com-financial/case-study/esg-andearnings-performance.pdf (accessed on 8 March 2020).

50. Friede, G.; Busch, T.; Bassen, A. ESG and financial performance: Aggregated evidence from more than 2000 empirical studies. J. Sustain. Financ. Investig. 2015, 5, 210-233. [CrossRef]

51. Hanson, D.; Lyons, T.; Bender, J.; Bertocci, B.; Lamy, B. Analysts' roundtable on Integrating ESG into investment decision-making. J. Appl. Corp. Financ. 2017, 29, 44-55. [CrossRef]

52. IHS Market. Review of Fixed Income Markets in 2015. Available online: https://ihsmarkit.com/research-analysis/08122015 -Credit-Review-of-fixed-income-markets-in-2015.html (accessed on 15 April 2020).

53. Polbennikov, S.; Desclée, A.; Dynkin, L.; Maitra, A. ESG ratings and performance of corporate bonds. J. Fixed Income 2016, 26, 21-41. [CrossRef]

54. Schneider, T. Is Enviromental Performance a Determinant of Bond Pricing? Evidence from US Pulp and Paper and Chemical Industries. Contemp. Account. Res. 2011, 28, 1537-1561. [CrossRef]

55. Bauer, R.; Hann, D. Corporate Environmental Management and Credit Risk; ECCE Working Paper; Maastricht University: Maastricht, The Netherlands, 2010. Available online: http:/ / ssrn.com/abstract=1660470 (accessed on 8 March 2021).

56. PRI (Principles for Responsible Investment). Corporate Bonds: Spotlight on ESG Risks, London. 2013. Available online: http / / www.unpri.org/fixed-income/corporate-bonds-spotlight-on-esg-risks / 40.article (accessed on 8 March 2020).

57. Bhojraj, S.; Sengupta, P. Effect of corporate governance on bond ratings and yields: The role of institutional investors and outside directors. J. Bus. 2003, 76, 455-475. [CrossRef] 
58. Klock, M.; Mansi, S.; Maxwell, W. Does corporate governance matter to bondholders? J. Financ. Quant. Anal. 2005, 40, 693-719. [CrossRef]

59. Attig, N.; El Ghoul, S.; Guedhami, O.; Suh, J. Corporate social responsibility and credit ratings. J. Bus. Ethics 2013, 117, 679-694. [CrossRef]

60. Wilkins, M. Climate Risk Increasingly Important for Ratings, Says S\&P. Environmental Finance, 24 November 2017.

61. Baker, M.; Bergstresser, D.; Serafeim, G.; Wurgler, J. Financing the Response to Climate Change: The Pricing and Ownership of U.S. Green Bonds; NBER Working Papers 25194; National Bureau of Economic Research, Inc.: Cambridge, MA, USA, 2018.

62. Flammer, C. Corporate Green Bonds. J. Financ. Econ. (JFE) 2018. [CrossRef]

63. Karpf, A.; Mandel, A. Does it Pay to Be Green? A Comparative Study of the Yield Term Structure of Green and Brown Bonds in the US Municipal Bonds Market. Working Paper. 2017. Available online: http:/ / dx.doi.org/10.2139/ssrn.2923484 (accessed on 24 February 2017).

64. Zerbib, O.D. The effect of pro-environmental preferences on bond prices: Evidence from green bonds. J. Bank. Financ. 2019, 98, 39-60. [CrossRef]

65. Flammer, C. Green bonds: Effectiveness and implications for public policy. Environ. Energy Policy Econ. 2020, 1, 95-128. [CrossRef]

66. Maltais, A.; Nykvist, B. Understanding the role of green bonds in advancing sustainability. J. Sustain. Financ. Investig. 2020, 1-20. [CrossRef]

67. Yin, R.K. Case Study Research: Design and Methods, 5th ed.; Sage Publications: Thousand Oaks, CA, USA, 2014.

68. Easterby-Smith, M.; Thorpe, R.; Jackson, P.R. Management \& Business Research, 5th ed.; SAGE: Los Angeles, CA, USA, 2015.

69. Saunders, M.; Lewis, P.; Thornhill, A. Research Methods for Business Students, 7th ed.; Pearson Education Limited: Essex, UK, 2016.

70. Eisenhardt, K.M. Building Theories from Case Study Research. Acad. Manag. Rev. 1989, 14, 532-550. [CrossRef]

71. Bezemer, P.-J.; Nicholson, G.; Pugliese, A. The Influence of Board Chairs on Director Engagement: A Case-Based Exploration of Boardroom Decision-Making. Corp. Gov. Int. Rev. 2018, 26, 219-234. [CrossRef]

72. McNulty, T.; Zattoni, A.; Douglas, T. Developing Corporate Governance Research Through Qualitative Methods: A Review of Previous Studies. Corp. Gov. Int. Rev. 2013, 21, 183-198. [CrossRef]

73. Fischer, F. Policy inquiry in a post-positivist perspective. Policy Stud. J. 1998, 26, 129-146. [CrossRef]

74. Brinkmann, S.; Kvale, S. Doing Interviews, 2nd ed.; Sage Publications: London, UK, 2011.

75. Berg, B.L.; Lune, H. Qualitative Research Methods for the Social Sciences, 8th ed.; Pearson Education: Harlow, UK, 2013.

76. Eisenhardt, K.M.; Graebner, M.E. Theory Building from Cases: Opportunities and Challenges. Acad. Manag. J. 2007, 50, 25-32. [CrossRef]

77. Patton, M.Q. Qualitative Research and Evaluation Methods, 3rd ed.; Sage Publications: Thousand Oaks, CA, USA, 2002.

78. Casadesus-Masanell, R.; Ricart, J.E. How to Design a Winning Business Model. Harvard Business Review. January-February 2011. Available online: https:/ /hbr.org/2011/01/how-to-design-a-winning-business-model (accessed on 15 November 2020).

79. Becker, H. Tricks of the Trade: How to Think About Your Research While You're Doing It; Chicago University Press: Chicago, IL, USA, 1998.

80. EIA U.S. Energy Information Administration. Geothermal Explained. 2020. Available online: https://www.eia.gov/ energyexplained/geothermal/geothermal-energy-and-the-environment.php (accessed on 15 November 2020).

81. Sigurjonsson, O.; Schwarzkopf, D.L.; Bryant, M. (Eds.) The Return of Trust? Institutions and the Public after the Icelandic Financial Crisis; Emerald Publishing: Bingley, UK, 2018. [CrossRef]

82. Reykjavik Energy. Ownership Strategy. 2014. Available online: https://www.or.is/en/about-or/organization-and-corporategovernance/owners-policy / (accessed on 2 November 2019).

83. Reykjavik Energy. Green Bond Framework. 2019. Available online: https://www.or.is/en/finance/financing/green-bondframework/ (accessed on 12 November 2020).

84. Reykjavik Energy. Annual Report 2015; Reykjavik Energy: Reykjavik, Iceland, 2015.

85. Reykjavik Energy. Annual Report 2018; Reykjavik Energy: Reykjavik, Iceland, 2018; Available online: https: / / annualreport2018.or. is/ (accessed on 2 November 2019).

86. United Nations Global Compact. Integrating the SDGs into Corporate Reporting: A Practical Guide. UN Report. 2018. Available online: https: / / www.unglobalcompact.org/library/5628 (accessed on 13 April 2020).

87. International Capital Market Association (IMCA). Green Bond Principles: Voluntary Process Guidelines for Issuing Green Bonds. 2019. Available online: https://www.icmagroup.org/green-social-and-sustainability-bonds/green-bond-principles-gbp/ (accessed on 12 December 2019).

88. Bryson, J.M. What To Do When Stakeholders Matter: Stakeholder Identification and Analysis Techniques. Public Manag. Rev. 2004, 6, 21-53. [CrossRef] 